\title{
Covid-19: pandemic healthcare centres should have already existed
}

\author{
Neel Sharma clinician academic in gastroenterology ${ }^{1}$, Diana Anderson clinical fellow in geriatric \\ medicine $^{2}$
}

${ }^{1}$ Queen Elizabeth Hospital Birmingham, Birmingham B15 2TH, UK; ${ }^{2}$ University of California San Francisco, San Francisco, CA 94121, USA

Too little too late are the words being uttered by medical professionals in both the UK and US at the rising numbers of confirmed covid-19 cases and deaths. ${ }^{1}$ Healthcare architects and engineers support these sentiments given the frantic scramble for adaptive reuse of existing spaces to deliver care. ${ }^{1}$ Knowing weeks in advance of the global spread of this virus did little to spark momentum in the US and UK health systems to prepare early for what lay ahead.

Now we face the consequences of untimely infrastructure action. Delays in understanding how best to house patients and protect healthcare workers have prompted multifaceted solutions for spaces and equipment to deliver effective care. The rising numbers of confirmed cases have led to makeshift centres being erected at record speed. But these centres should have already existed.

Pandemics have long been a concern for populations. The temporary centres we now see as salvage measures are being arranged when many lives have already been lost. To support the pandemic response, architects and engineers are now thinking about developing existing shell spaces, repurposing existing buildings, developing mobile modular critical care units that can be quickly deployed in existing arenas or installed in outdoor spaces, and using religious buildings to make room for infected patients.

We hope that when the next pandemic arises, field hospitals such as the UK's NHS Nightingale and New York City's Javits Center have remained permanent features ready for action and don't need to be resurrected while we watch people die. We should not be waiting for the curve to spike until we find makeshift hospitals for our patients. Pandemic ready centres need to be considered essential for future generations.

Competing interests: None declared.

Moberly T. From conference centre to hospital. BMJ 2020;368:m1298. 10.1136/bmj.m1298 32234731

Published by the BMJ Publishing Group Limited. For permission to use (where not already granted under a licence) please go to http://group.bmj.com/group/rights-licensing/ permissions 